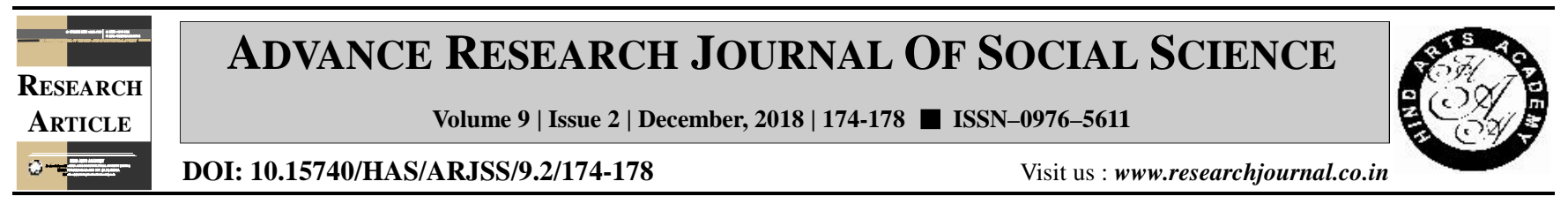

\title{
Opinion of college youth regarding solemnization of marriage
}

Shatakshi Purohit* and Renu Dhakar

Department of Human Development and Family Studies, Maharana Pratap University of Agriculture and Technology, Udaipur (Rajasthan) India

Email : purohitshatakshi@gmail.com

\section{ARTICLE INFO :}

$\begin{array}{lll}\text { Received } & : & 12.06 .2018 \\ \text { Revised } & : & 08.11 .2018 \\ \text { Accepted } & : & 12.11 .2018\end{array}$

KEY WORDS :

Early youth (18-21 years), Late youth (24-27 years), College youth

\section{HOW TO CITE THIS ARTICLE :}

Purohit, Shatakshi and Dhakar, Renu (2018). Opinion of college youth regarding solemnization of marriage. $A d v$. Res. J. Soc. Sci., 9 (2) : 174-178, DOI: 10.15 740/HAS/ARJSS/9.2/174-178. Copyright@2018 : Hind Agri Horticultural Society

*Author for correspondence

\begin{abstract}
The present research was conducted to study the opinion of college youth regarding significance of marriage. The data was collected from 60 early youth and 60 late youth pursuing professional and non- professional degrees. 'Questionnaire on selected aspects of marriage among college youth' was developed and utilized to collect information. The data was analyzed through frequency distribution and percentage method. The study has revealed the opinion of college youth regarding procedure of marriage.
\end{abstract}

